\title{
SISTEM PERKULIAHAN BERBASIS E-LEARNING PADA FAKULTAS TEKNOLOGI INFORMASI DAN KOMUNIKASI UNIVERSITAS SEMARANG
}

\author{
Henny Indriyawati ${ }^{1}$, Didin Herlinudinkhaji ${ }^{2}$ Soiful Hadi ${ }^{3}$ \\ ${ }^{1}$ Program Studi Sistem Informasi Fakultas Teknologi Informasi dan Komunikasi, Universitas Semarang \\ Jl. Soekarno Hatta, Semarang 50196, e-mail: henny@usm.ac.id \\ ${ }^{2}$ Program Studi Teknik Informatika Universitas Slamet Sri Kendal \\ Jl. Soekarno Hatta, Semarang 50196, e-mail: henny@usm.ac.id \\ ${ }^{3}$ Program Studi Sistem Informasi Fakultas Teknologi Informasi dan Komunikasi, Universitas Semarang \\ Jl. Soekarno Hatta, Semarang 50196, e-mail: saifu@usm.ac.id
}

\section{ARTICLE INFO}

Article history:

Received 8 Agustus 2018

Received in revised form 10 Agustus 2018

Accepted 14 September 2018

Available online 17 Agustus 2018

\section{ABSTRACT}

Sistem perkuliahan yang terdapat pada Fakultas Teknologi Informasi dan Komunikasi (FTIK) menggunakan sistem pertemuan tatap muka sehingga dosen diharuskan tatap dengan mahasiswa sesuai dengan aturan. Penggunaan metode ceramah yang dilakukan oleh para dosen dengan menggunakan modul yang kurang menarik mengakibatkan mahasiswa yang lemah pada penghafalan dan susah mengingat-mengingat rumus dan sintaks pemrograman yang diberikan oleh dosen mengakibatkan mahasiswa malas belajar dan bosan. Perkuliahan online merupakan salah satu sarana pembelajaran interaktif yang memungkinkan dosen dan mahasiswanya dapat berkomunikasi tanpa bertatap muka secara langsung yaitu dengan menggunakan media online. Dosen dan mahasasiswa dapat berkomunikasi dengan mengunakan media internet dengan perangkat lunak dan pendukung. Dosen dapat memberikan informasi-informasi penting kepada para mahasiswa dengan memanfaatkan perkuliahan online. Hal ini yang kemudian menjadikan alasan untuk memanfatkan teknologi informasi untuk menerapkan sistem perkuliahan online berbasis e-learning dengan menerapkan prinsip fleksibilitas, efektif, dan efisien Keywords: e-learning, kuliah online

\section{Pendahuluan}

E-learning memungkinkan pembelajar untuk tetap dapat menimba ilmu tanpa harus secara fisik menghadiri kelas. Kegiatan belajar menjadi fleksibel karena dapat disesuaikan dengan ketersediaan waktu para pembelajar. Kegiatan pembelajaran terjadi melalui interaksi pembelajar dengan sumber belajar yang tersedia dan dapat diakses dari [1]. Beberapa usaha dilakukan untuk peningkatan kualitas proses pembelajaran maka diperlukan adanya upaya pengembangan suatu media pembelajaran yang bersifat interaktif berupa pembelajaran berbasis computer dan internet 
[5]. E-learning atau biasa disebut dengan nama electroning learning merupakan salah satu media untuk melakukan proses belajar mengajar dengan memnfaatkan internet sebagai model pembelajarannya. E-learning menerapkan proses pembelajaran dengan bantuan media jaringan (LAN,WAN, maupun internet) dengan menerapkan prinsip fleksibilitas, efektif, interaktif, dan efisien.

Fakultas Teknologi Informasi dan Komunikasi Universitas Semarang merupakan salah satu fakultas yang terdapat pada universitas di Semarang dengan jumlah mahasiswa yang besar. Penggunaan metode ceramah yang dilakukan oleh para dosen dengan menggunakan modul yang kurang menarik mengakibatkan mahasiswa yang lemah pada penghafalan dan susah mengingatmengingat rumus dan sintaks pemrograman yang diberikan oleh dosen mengakibatkan mahasiswa malas belajar dan bosan. Hal ini memungkinkan terjadinya kebosanan mahasiswa terhadap dosennya karena menggunakan model pembelajaran yang monoton.

Hal ini yang kemudian menjadikan alasan memanfatkan teknologi informasi untuk menerapkan sistem perkuliahan online berbasis e-learning dengan menerapkan prinsip fleksibilitas, efektif, dan efisien. Sistem e-learning dibangun untuk membantu proses belajar dan mengajar dalam akademik. Dengan e-learning mahasiswa dapat mengambil materi perkuliahan, evaluasi yang berkaitan dengan perkuliahan tanpa harus datang ke kampus.

Pada penelitian ini akan diteliti tentang sistem e-learning pada Fakultas Teknologi Informasi dan Komunikasi Universitas Semarang.

\section{Penelitian Terkait}

Media merupakan bentuk dan saluran yang digunakan sebagai proses informasi [4]. Pembelajaran adalah proses komunikasi antara pembelajar, pengajar danbahan ajar. Secara umum, media pembelajaran adalah bentuk saluran yang dapat digunakan untuk menyalurkan suatu pesan, informasi, atau sebagai alat bantu proses dalam belajar mengajar [4]. E-learning adalah instruksi yang disampaikan melalui perangkat elektronik digital seperti komputer atau perangkat mobile yang ditujukan untuk menunjang proses pembelajaran [2]. E-learning adalah pemanfaatan teknologi informasi dan komputer untuk membangun pengalaman belajar [6].

\section{Metode Penelitian}

Jenis data yang digunakan adalah data pembelajaran yang diajarkan dosen FTIK dan buku yang terkait dengan penelitian ini. Metode pengembangan sistem yang digunakan dalam penelitian ini adalah System Development Live Cycle(SDLC), yaitu suatu pendekatan proses dalam komunikasi data yang menggambarkan siklus yang tiada awal dan akhir dalam sistem, mencakup tahapan Analisis, Desain, Implementasi, Pengujian [3].

\section{Hasil dan Pembahasan}

\subsection{Analisis Kebutuhan}

Dalam penelitian ini analisis yang dilakukan adalah mengidentifikasi yang dibutuhaan user yaitu sebuah sistem yang mudah dalam pengelolaan, aksesnya cepat, disediakan fasilitas chat ataupun forum,melihat hasil tes, dan dapat melihat serta dapat mencetak laporan.

\subsection{Analisis kebutuhan Hardware}

Mencakup perangkat keras yang digunakan untuk menganalisis layanan sistem informasi dengan spesifikasi Prosesor minimal speed $2.00 \mathrm{GHz}$, RAM minimal $512 \mathrm{MB}$, Hardisk minimal free space $1 \mathrm{~GB}$

\subsection{Analisis Kebutuhan Software}

Perangkat lunak yang digunakan untuk mengelola kuliah online berupa sistem operasi windows 7, microsoft office 2007, PHP My Admin, WinSCP, perangkat browser. 


\subsection{Analisis Braindware}

Pengguna ini bertindak sebagai administrator dalam sistem. Admin merupakan pengelola sistem yang bertugas bertanggung jawab penuh terhadap kelangsungan sistem, bertanggung jawab terhadap database, menambahkan dan menghapus user, kategori/prodi, Mengaktifkan dan menonaktifkan user, modul, Bertanggung jawab terhadap keamanan sistem.

\subsection{Analisis Sistem Baru}

UML adalah salah satu standar bahasa yang banyak digunakan di dunia industri untuk mendefinisikan requirement, membuat analisi dan desain, serta menggambarkan arsitektur dalam pemrograman berorientasi objek. UML merupakan bahasa visual untuk pemodelan dan komunikasi mengenai sebuah sistem dengan menggunakan diagram dan teks-teks pendukung. UML muncul karena adanya kebutuhan pemodelan visual untuk menspesifikasikan, menggambarkan, membangun, dan dokumentasi dari sistem perangkat lunak [8].

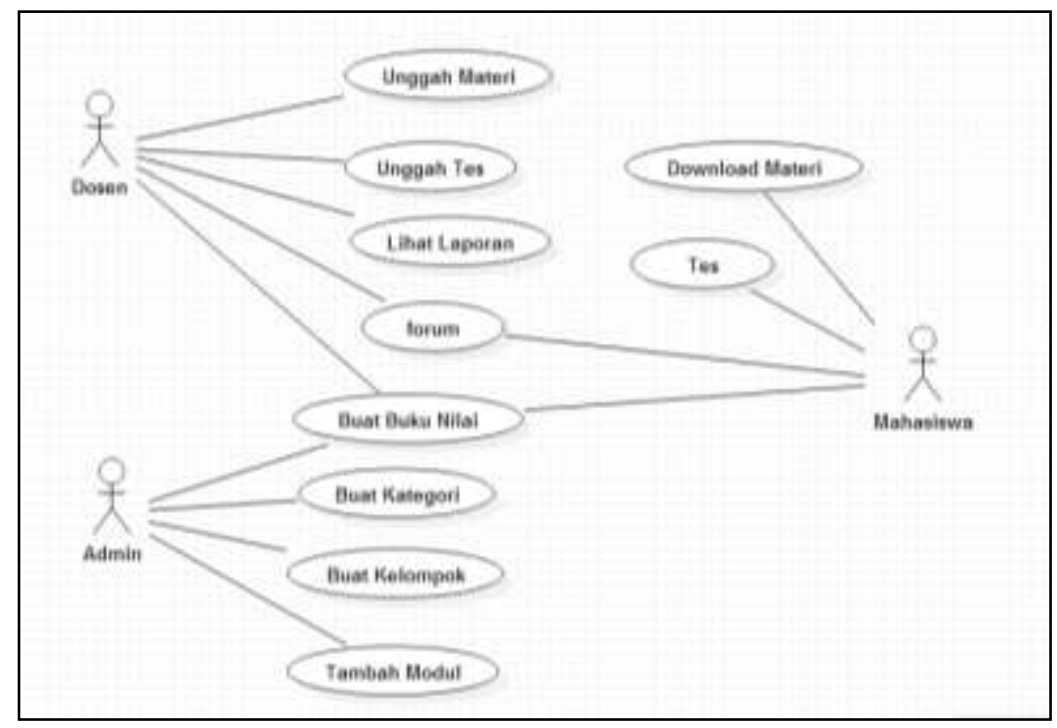

Gambar 1. Use Case Diagram e-learning

Gambar 1 menunjukkan fingsi yang ada didalam sistem. UML merupakan bahasa visual untuk pemodelan dan komunikasi mengenai sebuah sistem dengan menggunakan diagram dan teks-teks pendukung. UML muncul karena adanya kebutuhan pemodelan visual untuk menspesifikasikan, menggambarkan, membangun, dan dokumentasi dari sistem perangkat lunak [8].

\subsection{Implementasi Sistem}

Pada tahapan ini terdiri dari tahapan tahapan proses bisnis pada efront, deskripsi tentang kebutuhan sistem, pemodelan sistem, membuat database yang dibutuhkan, antar muka sistem. Aplikasi eFront memiliki tujuan utama yaitu proses bisnis yang terjadi antara student (mahasiswa) dengan profesor (dosen). Proses ini terjadi pada saat mahasiswa mendapatkan materi melalui aplikasi ini, mahasiswa juga dapat mengerjakan tugas-tugas ataupun tes yang diberikan oleh profesor.

a. Profesor (dosen) memberikan materi ajar.

Aplikasi ini dapat menambahkan materi ajar sesuai dengan materi yang diberikan. Upload materi yang disediakan berupa file image, ataupun text. Maksimal upload materi adalah 2048 KB.Penambahan materi ajar dilihat pada Gambar 2.

TRANSFORMATIKA Vol. 16, No. 1, Juli 2018: 98 - 105 


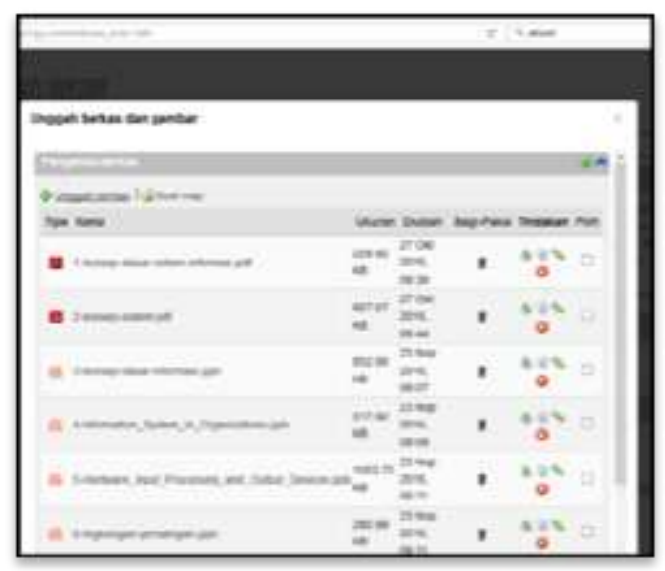

Gambar 2. Form Unggah Materi

b. Student (mahasiswa) mendapatkan materi dan menyelesaikannya.

Mahasiswa yang sudah mendaftar pada mata kuliah yang sudah dibuat oleh dosen berhak mendapatkan materi dan juga dapat menyelesaikan materi secara online. Gambar 3 menunjukkan materi ajar yang sudah di unggah dosen dan dapat di unduh oleh pengguna.

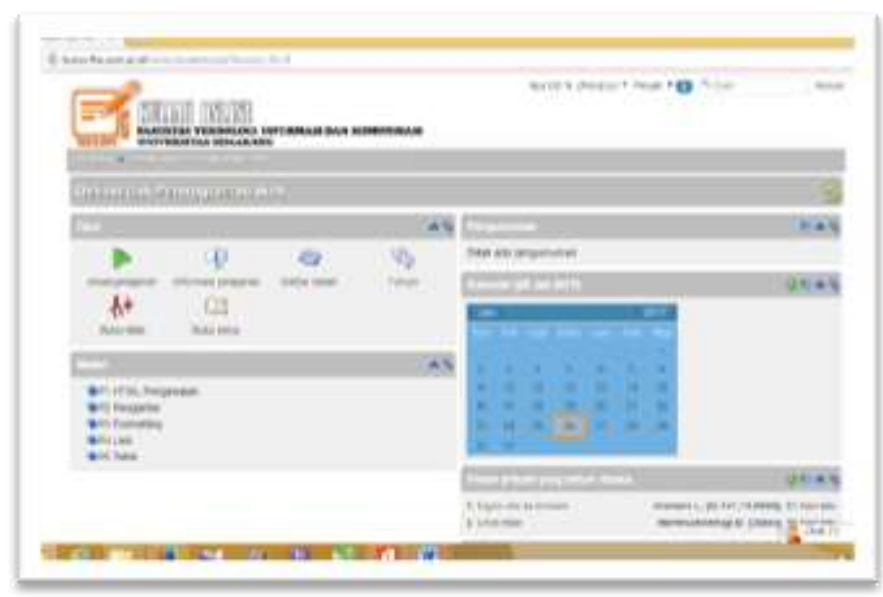

Gambar 3. Form Materi Pelajaran

c. Profesor (dosen) memberikan tugas dan tes.

Dosen memberikan tugas berdasarkan lama pengerjaannya dengan memperhatikan aspek pengetahuan. Dosen juga dapat memberikan evaluasi berupa tes secara online.

Gambar 4menunjukkan tugas dan Gambar 5 menunjukan evaluasi secara true/false. 

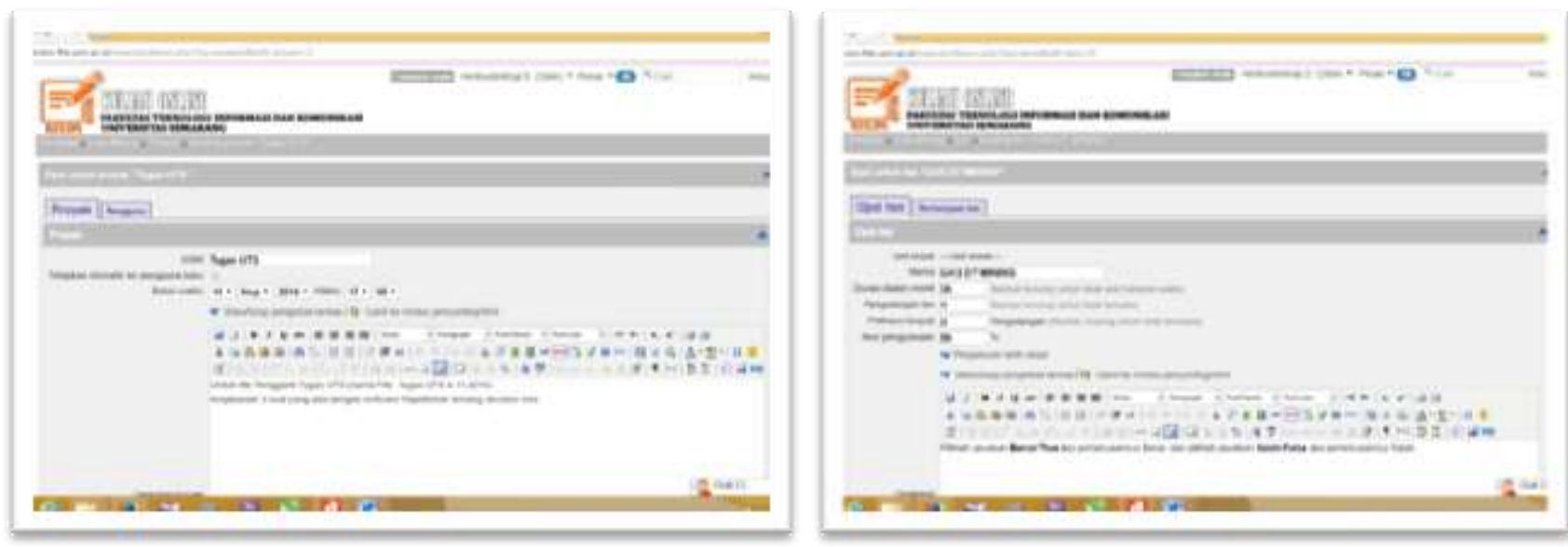

Gambar 4 Form tugas berdasarkan batas waktu pengerjaan dan form evaluasi true/ false

d. Student (mahasiswa) mengumpulkan tugas dan menyelesaikan tes secara online.

Mahasiswa yang sudah mendaftar pada mata kuliah yang sudah dibuat oleh dosen akan mendapatkan tugas yang diberikan oleh profesor yang sudah diberikan batas waktu pengumpulannya. Pengguna juga akan mendapatkan tes yang diberikan oleh profesor sesuai dengan jenis tes yang dibuat oleh profesor dengan batas waktu pengerjaan. Gambar 5 menunjukkan tugas dengan ketentuan waktu pengumpulan dan menunjukkan tes dengan estimasi waktu pengerjaan.
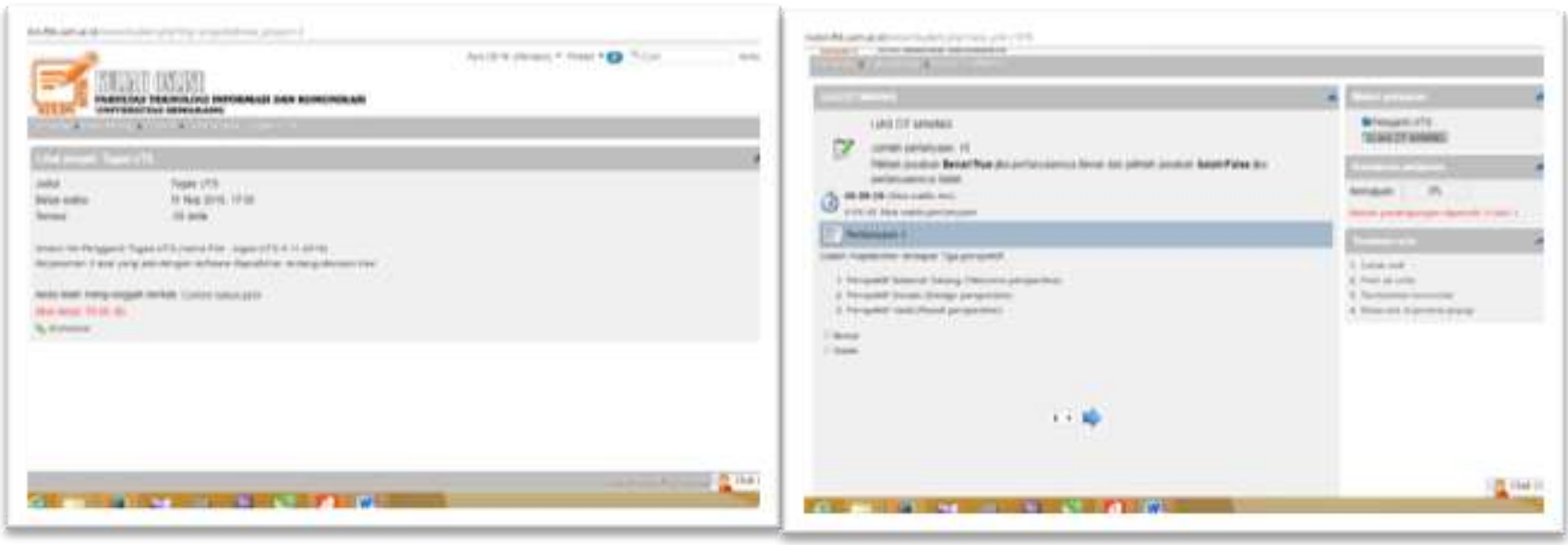

Gambar 5 Form tugas dan Form tes dengan estimasi waktu pengerjaan

e. Form pendaftaran dan login.

Tampilan login pada gambar 6 menunjukkan bahwa login tersebut berdasarkan user name yang sudah terdaftar. 

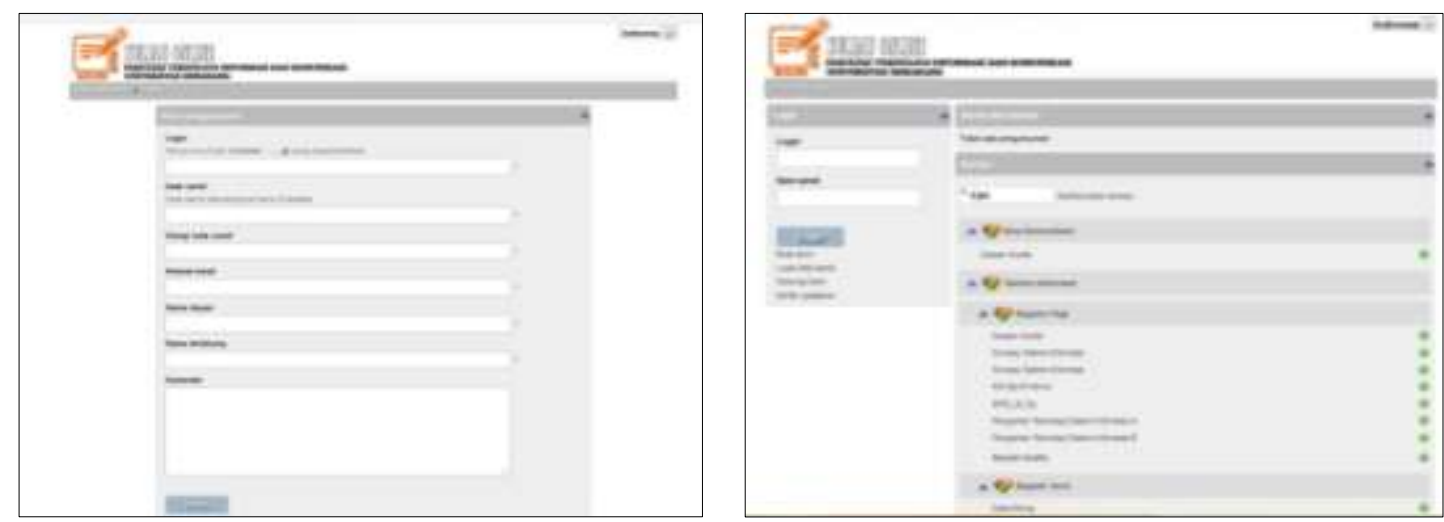

Gambar 6 Tampilan Form Pendaftaran dan login

f. Tampilan Form Utama admin dan professor

Tampilan utama yang diberikan oleh eFront terdiri dari admin, profesor, dan student.
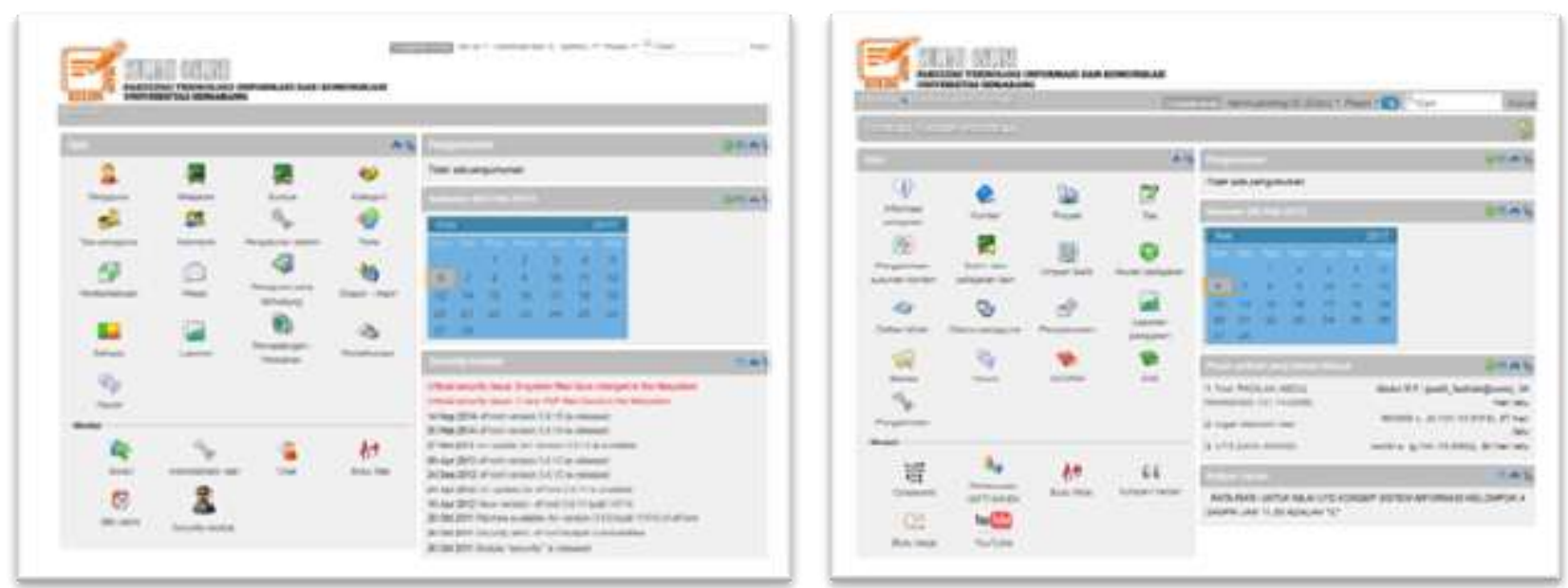

Gambar 7 Tampilan menu utama admin dan professor

Tampilan Form Utama Student

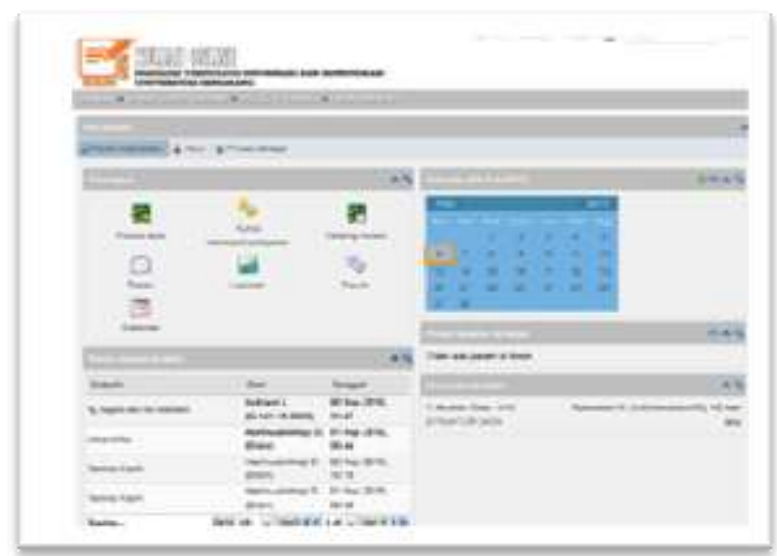

Gambar 9 Tampilan form utama student 
g. Tampilan Form Penilaian Tes

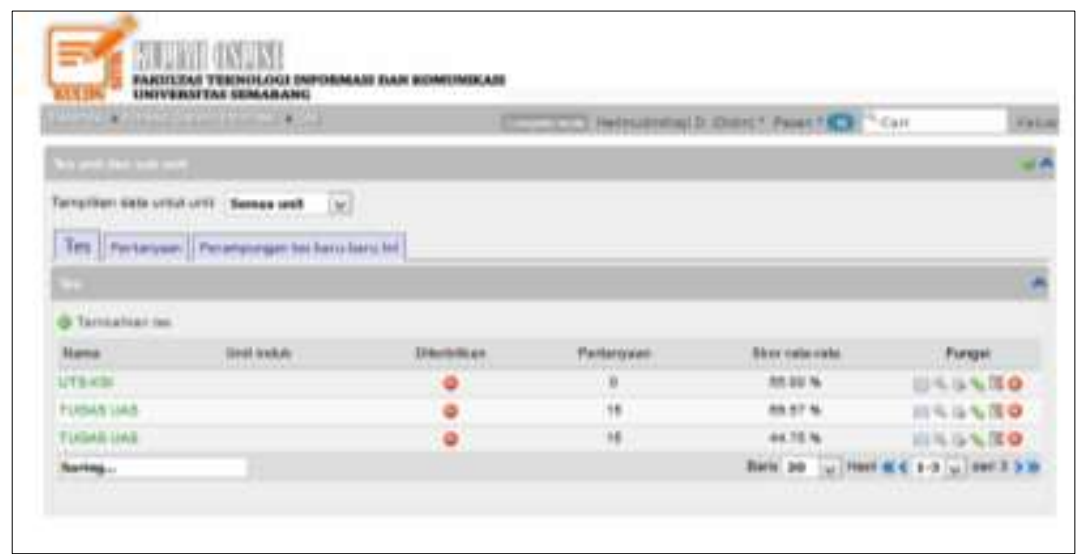

Gambar 10 Tampilan form penilaian tes

h. Laporan Buku Nilai

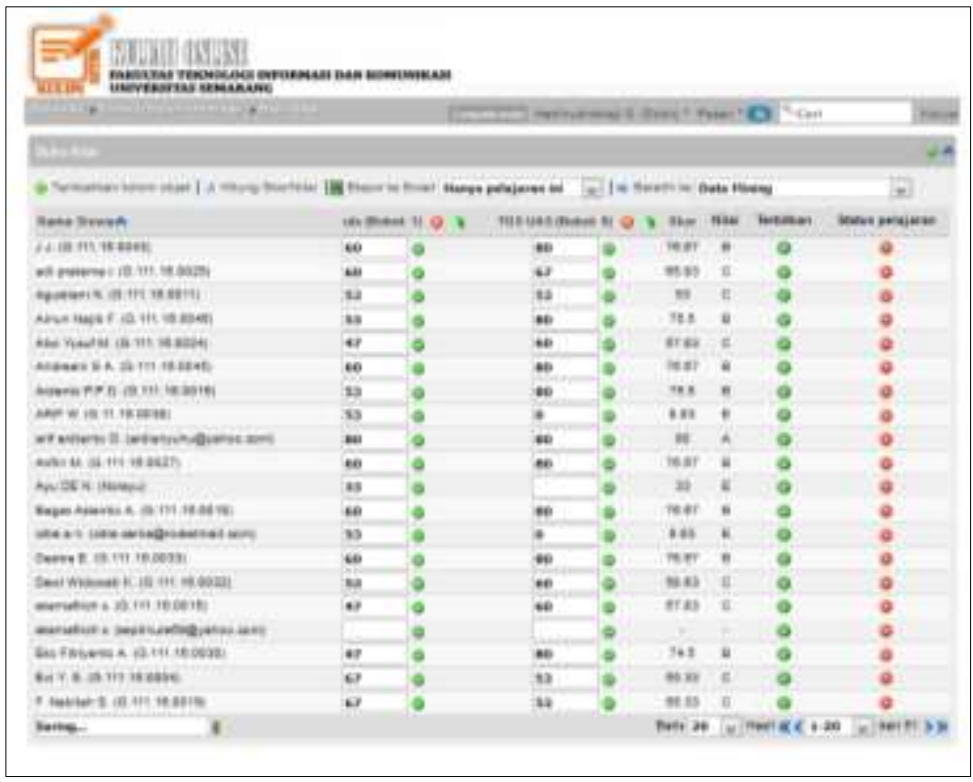

Gambar 5.25 Tampilan Buku Nilai

\section{Kesimpulan}

Kesimpulan yang dapat penulis sajikan dalan penulisan laporan penelitian ini adalah :

Membangun sistem perkuliahan online berbasis e-learning. Membuat media pembelajaran yang inovatif dan kompetitif. Sistem e-learning ini sudah digunakan oleh dosen jurusan Teknologi Informasi dengan alamat URL http://kulon.ftik.usm.ac.id 


\section{REFERENCES}

[1]. Ariani, Niken. Dan Haryanto, Dany. 2010. Pembelajaran Multimedia di Sekolah. Jakarta: Prestasi Pustaka.

[2]. Clark, R., \& Mayer, R. (2011). E-Learning and the science of instruction: Proven guidelines for consumers and designers of multimedia learning. John Wiley \& Son.

[3]. Nugroho, Adi, 2010, Rekayasa Perangkat Lunak Berorientasi Objek dengan Metode USDP (Unified Software Development Process), Andi, Yogyakarta.

[4]. Nurseto, Tejo. Membuat Media Pembelajaran yang Menarik, Jurnal Ekonomi \& Pendidikan, Vol. 8, No. 1. 2011.

[5]. Priyanto, Dwi,Pengembangan Multimedia Pembelajaran Berbasis Komputer. Jurnal Pemikiran Alternatif Pendidikan. Vol.14. No.1. 2009.

[6]. Seprida Hanum Harahap,2015, Pemanfaatan E-Learning Berbasis Lcms Moodle Sebagai Media Pembelajaran Untuk Mata Kuliah Sistem Informasi Akuntansi, Jurnal Riset Akuntansi Dan Bisnis. Vol. 15 No.1/ Maret 2015

[7]. Rosa, A. S. Dan M. Shalahuddin, 2013, Rekayasa Perangkat Lunak, Informatika, Bandung. 